\title{
Ontogeny of Adenylate Cyclase Activity in the Rat Lung: Guanine Nucleotides and Cytosolic Factors
}

\author{
JEFFREY A. WHITSETT, ${ }^{(42)}$ CHARLOTTE DAROVEC-BECKERMAN, AND WARD R. RICE \\ Children's Hospital and Department of Pediatrics, Newborn Division, University of Cincinnati College of Medicine, \\ Cincinnati, Ohio, USA
}

\begin{abstract}
Summary
Catecholamines mediate surfactant release, smooth muscle tone, and lung fluid secretion presumably by their interactions with $\beta$-adrenergic receptors and adenylate cyclase, which results in the synthesis of $3^{\prime}, 5^{\prime}$ cyclic adenosine monophosphate (cAMP). Ontogenic changes in factors which regulate cAMP metabolism in the lung have been demonstrated previously and associated with developmental changes in lung structure and function in the perinatal period. In this study, developmental changes in characteristics of $\beta$-adrenergic receptors and the enzyme adenylate cyclase were characterized in rat lung from day 18 of gestation to adulthood. Although concentrations of pulmonary $\beta$-adrenergic receptors increased approximately 5 -fold during the perinatal and suckling period, "basal" adenylate cyclase activity of lung homogenates decreased from $130 \pm 8$ pmole $\cdot \mathrm{mg}^{-1} \cdot \mathrm{min}^{-1}$ at 20 days gestation to $25 \pm 3 \mathrm{pmole} \cdot \mathrm{mg}^{-1} \cdot \mathrm{min}^{-1}$ in the adult, $\mathbf{P}<0.01$. GTP and lung cytosol activated adenylate cyclase from fetal membranes to a significantly greater extent than they activated the enzyme from adult membrane. GTP enhanced adenylate cyclase activity 5-6-fold in fetal membranes, GTP being nearly as active as its non-hydrolyzable analogue $\mathrm{Gpp}(\mathrm{NH})$ p or $\mathrm{NaF}$. Addition of GTP in the presence of $P G E_{1}$ or catecholamine resulted in nearly maximal activation of the enzyme from fetal but not from adult lung membranes. Cholera toxin enhanced GTP-dependent activity in adult samples but did not further increase GTP-dependent activity in fetal preparations.

Lung cytosolic factor(s), which activated adenylate cyclase, were separated into two components by gel filtration. One activating component was likely to be GTP, which was present in lung tissue in concentrations near the EC50 for activation of adenylate cyclase. A second (large molecular weight) cytosolic factor(s), which activated adenylate cyclase, was sensitive to heat or trypsin and was excluded by Sephadex G-50. An ATP-regenerating system was required for full activation of adenylate cyclase by lung cytosol. Effects of EGTA, $\mathrm{Mg}^{2+}$, guanine nucleotides, cell cytosol and $\mathrm{Ca}^{2+}$-calmodulin were partially characterized.
\end{abstract}

\section{Abbreviations}

BSA, bovine serum albumin

$C$, catalytic subunit of adenylate cyclase

cAMP, 3', 5'-cyclic adenosine monophosphate

EC50, effective concentration to increase activity half-maximally

$\mathrm{G} / \mathrm{F}$, guanine nucleotide factor

Gpp(NH)p, guanosine- $5^{\prime}-(\beta, \gamma,-$ imino) triphosphate

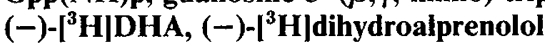

$\mathrm{PGE}_{1}$, prostaglandin $\mathrm{E}_{1}$

EGTA, ethylene glycol bis ( $\beta$-aminoethyl ether) $N, N, N^{1}, N^{1}$-tetra acetic acid

SDS, sodium dodecyl sulfate

ST, $250 \mathrm{mM}$ Sucrose, $10 \mathrm{mM}$ Tris-HCl (pH 7.2)

STE, $250 \mathrm{mM}$ Sucrose, $10 \mathrm{mM}$ Tris-HCl, $1 \mathrm{mM}$ EGTA (pH 7.2)
cAMP mediates cell differentiation, smooth muscle tone, fluid secretion, and surfactant release in various pulmonary cells $(2,9$, $21)$. Ontogenic changes in factors that regulate cAMP metabolism in the lung have been described and include changes in $\beta$-adrenergic receptors, catecholamine and prostaglandin sensitive adenylate cyclase activity, cAMP phosphodiesterase and cAMP-dependent protein kinase activities $(5,11,15,24-26,28,33,37,38)$. In previous studies from this laboratory and others, the interpretation of developmental changes in catecholamine-sensitive adenylate cyclase in rat and rabbit lung were complicated by changes in apparent "basal" adenylate cyclase activity found in crude homogenates $(1,23-26,28,37,38)$. Likewise there has been considerable discrepancy among various studies regarding ontogenic changes in hormone sensitivity between intact tissue and tissue homogenates. The factors involved in the developmental changes in adenylate cyclase activity were not clearly determined in these previous studies. The present study was therefore designed to clarify the possible mechanisms accounting for marked changes in "basal" and hormone-sensitive adenylate cyclase activity occurring during lung development.

Changes in a number of cellular factors, which regulate adenylate cyclase, might account for the ontogenic changes in adenylate cyclase activity previously observed. These factors include: (1) $\beta$-adrenergic receptor numbers or affinity; (2) the catalytic subunit of adenylate cyclase (C); and (3) their interactions with guanine-nucleotide-dependent proteins ( $\mathrm{G} / \mathrm{F}$ factors), guanine nucleotide, cytosolic factors, and cations such as $\mathrm{Mg}^{2+}$ and $\mathrm{Ca}^{2+}$ $(16,35)$.

Guanine nucleotides, guanine-nucleotide-dependent protein(s) $(\mathrm{G} / \mathrm{F})$ and $\mathrm{Mg}^{2+}$ are required for the expression of hormonesensitive adenylate cyclase $(16,35)$. Guanine nucleotides, which bind to a proposed regulatory site on $G / F$ protein(s), decrease agonist affinity at the receptor site and mediate hormonal activation of catalytic adenylate cyclase activity. The mechanism of interaction between agonist-occupied hormone receptors and adenylate cyclase $(\mathrm{C})$ is associated with hydrolysis of GTP from the $\mathrm{G} / \mathrm{F}$ site by a specific hormone-sensitive GTPase, which has been identified in pigeon erythrocyte. $G / F$ factor is ribosylated in a reaction catalyzed by cholera toxin, which inactivates GTPase activity of $G / F$ and results in stimulation of catalytic adenylate cyclase activity $(3,4,16,35)$. There is also evidence that $\mathrm{Mg}^{2+}$ and other cations serve as regulators of hormone-sensitive adenylate cyclase activity. $\mathrm{Mg}^{2+}$ increases agonist affinity for the receptor site and directly enhances catalytic activity by its interaction with $\mathrm{G} / \mathrm{F}$ factor(s) or catalytic subunit $(13,16,18,35,40)$. Finally, cytosolic factors have been identified in several tissues that might also play a role in ontogenic changes in adenylate cyclase in the lung $(6,7,20,23,26,27)$.

Developmental changes in any of these components of the hormone response system, i.e., hormone receptor, guanine-nucleotide-dependent factors, the catalytic subunit or their various GTP or cationic regulatory sites, might therefore be related to changes in cAMP synthesis and hormone sensitivity that occur in devel- 
oping lung. The present study was initiated to determine characteristics of interactions among $\beta$-adrenergic receptors, $\mathrm{G} / \mathrm{F}$ factors, guanine nucleotides, $\mathrm{Mg}^{2+}$, "cytosolic" factors and hormone-sensitive adenylate cyclase activity in crude homogenates and in membrane preparations from developing rat lung. In this work we demonstrate ontogenic changes in the activation of pulmonary adenylate cyclase by guanine nucleotide, $\mathrm{Mg}^{2+}$, and factors present in lung cytosol. We present evidence that lung cytosolic factor(s) activate adenylate cyclase with properties similar to activation by guanine nucleotides and not by $\mathrm{Ca}^{2+}$-calmodulin.

\section{MATERIALS AND METHODS}

Materials. (-)- $\left[{ }^{3} \mathrm{H}\right] \mathrm{DHA}(56 \mathrm{Ci} / \mathrm{mmole}) ;\left[\alpha^{32} \mathrm{P}\right]-\mathrm{ATP}(31 \mathrm{Ci} /$ mmole) and $\left[{ }^{3} \mathrm{H}\right] \mathrm{cAMP}$ were purchased from New England Nuclear Corp. (Boston, MA). Cholera toxin was purchased from Schwarz-Mann, Inc.; Sephadex G-50 (fine) was purchased from Pharmacia; and Gpp(NH)p was purchased from BoehringerMannheim. (-)-Isoproterenol bitartrate, GTP, and other reagents were purchased from Sigma Chemical Co. (St. Louis, MO). Calmodulin was the kind gift of James Potter, Ph.D., University of Cincinnati College of Medicine. Trifluoperazine was donated by Smith-Kline and French Laboratories.

Membrane preparation. Timed-bred Sprague-Dawley rats were purchased from Charles River Corp. Dams were fed standard rat chow and maintained at $24^{\circ} \mathrm{C}$ in a $12 \mathrm{~h}$ light-dark cycle. Animals were weighed and sacrificed by decapitation. Lungs from individual animals were dissected with care to remove tracheal and hilar structures, diced and placed in iced buffer containing $250 \mathrm{mM}$ sucrose, $1 \mathrm{mM}$ EGTA and $5 \mathrm{mM}$ Tris- $\mathrm{HCl}$, pH 7.2 (STE). In experiments to determine effects of EGTA and calcium $\left(\mathrm{Ca}^{2+}\right)$, preparations were made in buffer with (STE) or without EGTA (ST). Lung samples from entire litters (both male and female) were pooled for the prenatal samples. Lungs from two pups were pooled for each preparation on day 5 . Thereafter lungs were taken from individual animals. Adult samples reported were obtained from female rats; however, no sex related differences were noted in $\beta$-adrenergic receptors or adenylate cyclase in adult animals. Washed tissue was homogenized with a Tekmar Tissuemizer (Tekmar Co., Cincinnati, OH) in 10 volumes of sucrose buffer per wet weight of lung tissue by three 5 -sec bursts at high setting. Homogenate was poured through four layers of gauze and samples taken for protein, $(-)-\left[{ }^{3} \mathrm{H}\right] \mathrm{DHA}$ binding and adenylate cyclase determinations. This filtered homogenate was centrifuged at 3000 $\times g$ for $5 \mathrm{~min}$. The supernatant was centrifuged at $40,000 \times g$ for $20 \mathrm{~min}$ and the pellet resuspended by gentle homogenization in iced buffer and centrifuged again at $40,000 \times g$ for $20 \mathrm{~min}$. This washed pellet (membrane) was resuspenjed in homogenizing buffer to a final membrane protein concentration of $2-4 \mathrm{mg} / \mathrm{ml}$, as determined by the method of Lowry et al. using bovine serum albumin as standard (19). Cytosol was prepared by sedimenting the $40,000 \mathrm{~g}$ supernatant at $100,000 \times g$ for $1 \mathrm{~h}$. Samples were generally assayed for $\beta$-adrenergic receptors or adenylate cyclase activity within several days after freezing in dry ice-acetone bath and storage at $-70^{\circ} \mathrm{C}$. Catecholamine-sensitive adenylate cyclase activity and (-)- $\left[{ }^{3} \mathrm{H}\right] \mathrm{DHA}$ binding were determined in freshly prepared membrane and whole homogenates (the latter after filtration through four layers of gauze).

Adenylate cyclase assay. Adenylate cyclase was determined in triplicate at $30^{\circ} \mathrm{C}$ by the method of Salomon et al. (36). Lung protein $(20-40 \mu \mathrm{g})$ was incubated for $10-15 \mathrm{~min}$ in media containing $80 \mathrm{mM}$ Tris- $\mathrm{HCl}(\mathrm{pH} 7.4), 1 \mathrm{mM}\left[\alpha-{ }^{32} \mathrm{P}\right]-\mathrm{ATP}(1-2 \mu \mathrm{Ci}), 4.5$ $\left.\mathrm{mM} \mathrm{MgCl} 2,1 \mathrm{mM} \mathrm{[}{ }^{3} \mathrm{H}\right] \mathrm{cAMP}(0.003 \mu \mathrm{Ci})$, a creatine phosphokinase-ATP-regenerating system containing $10 \mathrm{U} / \mathrm{ml}$ creatine phosphokinase, $10 \mathrm{mM}$ phosphocreatine, $12.5 \mathrm{mM}$ sucrose, $0.05 \mathrm{mM}$ EGTA, and added hormone. All major experiments were initially performed both in the presence and absence of $5 \mathrm{mM}$ theophylline. In general, membrane and media were preincubated for $5 \mathrm{~min}$ at $30^{\circ} \mathrm{C}$ before the addition of $\left[\alpha-{ }^{32} \mathrm{P}\right]-\mathrm{ATP}$ (except in the case of time course experiments). Basal- and NaF-dependent activities increased linearly in proportion to time $(0-15 \mathrm{~min})$ and protein
(10-70 $\mu \mathrm{g})$. GTP-dependent activity increased in relation to time up to $20 \mathrm{~min}$. Activity decreased slightly thereafter. Both Gpp(NH)p and cytosol-dependent activity had a characteristic lag period $(1-2 \mathrm{~min})$ in the absence of hormone. The activity and its characteristics in membrane fractions from either adult or fetal lungs were stable during storage for at least 1 month when prepared in STE ( $\mathrm{pH}$ 7.2). Adenylate cyclase activity in the homogenate was lower in the absence of EGTA and was not stable during storage when ST (pH 7.2) was used as the homogenization buffer. Adenylate cyclase activity in ST-prepared membranes was also increased by addition of EGTA to the assay buffer. Free $\mathrm{Ca}^{2+}$ concentrations were estimated in the presence of the EGTA buffer system with 1 mM EGTA as described by Piascik et al. (30).

Column recoveries of $\left[{ }^{3} \mathrm{H}\right] \mathrm{cAMP}$ during the purification of $\left[{ }^{32} \mathrm{P}\right]$ cAMP were $60-70 \%$ during these studies and were not influenced by $5 \mathrm{mM}$ theophylline. Similarly $5 \mathrm{mM}$ theophylline did not enhance basal-, GTP-or cytosol-dependent activity in either fetal or adult membranes. Variation of cAMP determination was generally less than $5 \%$ in replicate samples. Significant differences between crude and washed fractions or in the presence and absence of agonist were determined by paired $t$ test. Differences in activity or agonist-dependent activity among various ages were determined by a one-way analysis of variance utilizing the Neuman-Kuels test. Differences between day 20 fetal and adult samples were assessed by Student's $t$ test. Significance is reported at the $P<0.05$ level.

Subcellular fractions. $\beta$-Adrenergic receptors and adenylate cyclase activity were present in crude homogenates and washed particulate membranes of rat lung at all ages studied. Recovery of protein and $\beta$-adrenergic receptors in membrane pellet was approximately $30 \%$ of starting activity. Recovery was similar in fetal and adult samples. $\beta$-Adrenergic receptors were enriched approximately 2 -fold in particulate membrane above the activity present in the starting homogenate in both fetal and adult samples (data not shown). In lung cytosol, adenylate cyclase activity was generally less than $2 \%$ of the activity in the washed membrane and was slightly higher in fetal than in postnatal samples.

Cholera toxin activation. Washed membrane $(500 \mu \mathrm{g})$ was incubated in $100 \mathrm{mM} \mathrm{NaCl}, 1 \mathrm{mM} \mathrm{GTP}, 10 \mathrm{mM}$ ATP, $1 \mathrm{mM} \beta$ NAD, $5 \mathrm{mM} \mathrm{MgCl}_{2}, 70 \mathrm{mM}$ sucrose, $50 \mathrm{mM}$ Tris- $\mathrm{HCl}, 0.1 \mathrm{mM}$ EGTA, and $10 \mu \mathrm{g} / \mathrm{ml} \mathrm{SDS}$-preactivated cholera toxin for $30 \mathrm{~min}$ at $37^{\circ} \mathrm{C}(10)$. Membranes were also incubated in this buffer in the absence of cholera toxin. Activated membrane was diluted in iced STE, centrifuged $40,000 \times g$ for $20 \mathrm{~min}$, resuspended in buffer (STE) and used immediately to determine adenylate cyclase activity.

Trypsin and heat denaturation. Cytosol $(100,000 \times g$ supernatant $)$ was incubated in the presence and absence of $1 \mathrm{mg} / \mathrm{ml}$ trypsin, 5 $\mathrm{mM} \mathrm{MgCl}_{2}$ in STE buffer. The reaction was terminated by addition of $1 \mathrm{mg} / \mathrm{ml} \mathrm{BSA}$ and $1 \mathrm{mg} / \mathrm{ml}$ lima bean trypsin inhibitor, (Sigma Chemical Co., St. Louis, MO). The ability of cytosol to stimulate adenylate cyclase was compared after treatment (I) with and without BSA; (2) with trypsin inhibitor and BSA; (3) with tryspin, BSA, and tyrpsin inhibitor; and (4) with trypsin, followed by addition of trypsin inhibitor and BSA. Ability of heat denatured (boiled 3-5 min) fetal and adult cytosol to activate adenylate cyclase was also tested with washed membranes from fetal and adult lung.

Tissue GTP, prostaglandins, and calmodulin activity. GTP levels in freshly dissected lung tissue from day 20 fetal and adult lung was determined after extraction in iced $1 \mathrm{M}$ percholoric acid by a modification of the method previously described for high pressure liquid chromatography using a linear gradient of $\mathrm{NaH}_{2} \mathrm{PO}_{4}, 0.01-$ $1.0 \mathrm{M},(\mathrm{pH} 2.8-4.8)$ to elute the column (34). Attempts to extract and measure GTP or recover added GTP from subcellular fractions containing STE buffer were unsuccessful. PGE was determined by a radioimmunoassay, which recognizes both $\mathrm{PGE}_{1}$ and $\mathrm{PGE}_{2}$ in tissue homogenates before and after incubation under conditions described for the adenylate cyclase assay (14). Calmodulin activity was assessed in heat-denatured lung cytosol by the 
activation of rat brain $\mathrm{Ca}^{2+}$-calmodulin sensitive cAMP phosphodiesterase as described by Dedman and Means (8).

$\left.(-)-\Gamma^{3} H\right]$ Dihydroalprenolol binding. Binding studies were performed in triplicate assays in buffer containing $10 \mathrm{mM} \mathrm{MgCl}, 50$ $\mathrm{mM}$ Tris- $\mathrm{HCl}$ (pH 7.4) and 30-60 $\mu \mathrm{g}$ of lung membrane protein as previously described $(37,38)$. Specific binding of $(-)-\left[{ }^{3} \mathrm{H}\right] \mathrm{DHA}$ (4 $\mathrm{nM})$ to crude membrane fractions was also determined to estimate total receptor number per lung and receptor recovery during preparation. In general, higher protein concentrations were used in fetal and neonatal samples because of lower receptor concentrations. The assay was initiated by addition of membrane protein. After incubation at $30^{\circ} \mathrm{C}$ for $20 \mathrm{~min}$, the reaction was terminated by addition of $4 \mathrm{ml}$ iced $\mathrm{Mg}$-Tris buffer, followed by rapid filtration through Whatman glass fiber filters (Whatman, Inc., Clifton, NJ). The filters were washed with an additional 16 $\mathrm{ml}$ iced $\mathrm{Mg}$-Tris buffer, dried and counted by standard liquid scintillation technique at $30 \%$ efficiency. Nonspecific binding was determined in triplicate assay containing $10^{-6} \mathrm{M}(-)$-alprenolol. This value was subtracted from total binding to determine specific binding. Nonspecific binding was identical whether obtained from competition with antagonist $\left[10^{-6} \mathrm{M}(-)\right.$-alprenolol] or agonist $\left[10^{-4} \mathrm{M}(-)\right.$-isoproterenol]. Triplicate assays generally varied less than $10 \%$ for both total and nonspecific binding. Scatchard plots of saturation experiments with $(-)-\left[{ }^{3} \mathrm{H}\right] \mathrm{DHA}$ and lung membrane were entirely linear. The $\mathrm{K}_{\mathrm{D}}(0.9 \mathrm{nM})$ did not change with age as reported previously (37). The effect of guanine nucleotide on agonist affinity for the receptor was determined in the presence and absence of $100 \mu \mathrm{M} \mathrm{Gpp}(\mathrm{NH}) \mathrm{p}$ as previously reported (39).

\section{RESULTS}

In order to evaluate ontogenic changes in hormone-sensitive adenylate cyclase activity, various components constituting the response system were partially characterized in fetal and adult preparations including: (I) $\beta$-adrenergic receptor number; (2) effect of $\mathrm{Mg}^{2+}$ and guanine nucleotides on receptor affinity; (3)

Table 1. $\left[{ }^{3} H\right] D H A$ binding and adenylate cyclase in crude lung homogenates during development ${ }^{1}$

\begin{tabular}{|c|c|c|c|}
\hline \multirow[b]{2}{*}{ Age (days) } & \multirow{2}{*}{$\begin{array}{c}{\left[^{3} \mathrm{H}\right] \mathrm{DHA}} \\
\text { binding } \\
\text { (fmole } \cdot \mathrm{mg}^{-1} \\
\text { protein) }\end{array}$} & \multicolumn{2}{|c|}{ Adenylate cyclase activity } \\
\hline & & Basal & $\begin{array}{c}\mathrm{NaF} \\
(10 \mathrm{mM})\end{array}$ \\
\hline \multicolumn{4}{|l|}{ Gestation } \\
\hline 19 & N.D. ${ }^{2}$ & $\begin{array}{l}111(104-118) \\
(n=2)\end{array}$ & $\begin{array}{c}262(255-269) \\
(n=2)\end{array}$ \\
\hline 20 & $\begin{array}{l}36 \pm 3^{3} \\
(n=7)\end{array}$ & $\begin{array}{r}130 \pm 7^{4} \\
(n=3)\end{array}$ & $\begin{array}{r}275 \pm 5^{4} \\
(n=3)\end{array}$ \\
\hline \multicolumn{4}{|l|}{ Postnatal } \\
\hline 5 & $\begin{array}{l}71 \pm 5^{3} \\
(n=4)\end{array}$ & $\begin{array}{c}151 \pm 18^{4} \\
(n=4)\end{array}$ & $\begin{array}{c}329 \pm 24^{4} \\
(n=4)\end{array}$ \\
\hline $14-15$ & $\begin{array}{l}116 \pm 6^{3} \\
(n=4)\end{array}$ & $\begin{array}{r}122 \pm 8^{4} \\
(n=4)\end{array}$ & $\begin{array}{c}222 \pm 12^{4} \\
(n=4)\end{array}$ \\
\hline $20-22$ & N.D. & $\begin{array}{r}101 \pm 5^{4} \\
(n=4)\end{array}$ & $\begin{array}{c}255 \pm 16^{4} \\
(n=3)\end{array}$ \\
\hline 28 & $\begin{array}{l}139 \pm 10^{5} \\
(n=10)\end{array}$ & $\begin{array}{l}46 \pm 5^{4} \\
(n=7)\end{array}$ & $\begin{array}{c}151 \pm 17 \\
(n=7)\end{array}$ \\
\hline Adult & $\begin{array}{c}162 \pm 2 \\
(n=4)\end{array}$ & $\begin{array}{l}25 \pm 2 \\
(n=9)\end{array}$ & $\begin{array}{c}123 \pm 15 \\
(n=9)\end{array}$ \\
\hline
\end{tabular}

${ }^{1}\left[{ }^{3} \mathrm{H}\right]$ DHA binding was determined at $4 \mathrm{nM}(-)-\left[{ }^{3} \mathrm{H}\right]$ DHA in fresh homogenates prepared from rat lung at each age; $n$ represents the number of separate preparations, mean \pm S.E.M. Specific and nonspecific binding was determined in triplicate as described in the "Materials and Methods." Adenylate cyclase was determined in each sample in triplicate in freshly prepared homogenates in the presence and absence of $10 \mathrm{mM} \mathrm{NaF}$. Adenylate cyclase values are pmole $\cdot \mathrm{mg}^{-1} \cdot \mathrm{min}^{-1}$, mean \pm S.E.M.

${ }^{2}$ N.D., not determined.

${ }^{3}<$ Adult $P<0.01$

${ }^{4}>$ Adult $P<0.01$

"5 $<$ Adult $P<0.05$.
Table 2. Adenylate cyclase in crude homogenate from fetal and adult rat lung (pmole $\left.\cdot \mathrm{mg}^{-1} \cdot \mathrm{min}^{-1} c A M P\right)^{1}$

\begin{tabular}{|c|c|c|}
\hline & Fetal (day 20) & Adult \\
\hline Basal & $135 \pm 16$ & $33 \pm 5$ \\
\hline $\operatorname{GTP}\left(10^{-5} \mathrm{M}\right)$ & $215 \pm 34$ & $49 \pm 8$ \\
\hline $\mathrm{PGE}_{1}\left(2.5 \times 10^{-5} \mathrm{M}\right)$ & $243 \pm 30$ & $52 \pm 9$ \\
\hline $\mathrm{PGE}_{1}+\mathrm{GTP}$ & $319 \pm 44$ & $86 \pm 13$ \\
\hline Isoproterenol $\left(10^{-5} \mathrm{M}\right)$ & $170 \pm 23$ & $50 \pm 8$ \\
\hline Isoproterenol + GTP & $251 \pm 40$ & $70 \pm 11$ \\
\hline $\mathrm{MgCl}_{2}(50 \mathrm{mM})$ & $128 \pm 11$ & $27 \pm 5$ \\
\hline $\mathrm{MgCl}_{2+}+\mathrm{GTP}$ & $219 \pm 30$ & $40 \pm 7$ \\
\hline $\mathrm{NaF}(10 \mathrm{mM})$ & $304 \pm 39$ & $145 \pm 21$ \\
\hline
\end{tabular}

${ }^{1}$ Adenylate cyclase was determined in fresh homogenate of fetal and adult lung in triplicate assay after $10 \mathrm{~min}$ incubation at $30^{\circ} \mathrm{C}$ as described in "Materials and Methods." Significant differences related to agents were determined by paired $\mathrm{t}$ test. All agents except $50 \mathrm{mM} \mathrm{MgCl} 2$ significantly enhanced enzyme activity, $P<0.01$. Values are mean \pm S.E.M.; $n=$ five preparations.

ability of catecholamines, guanine nucleotides, $\mathrm{Mg}^{2+}$ and $\mathrm{NaF}$ to stimulate adenylate cyclase; (4) ability of cholera toxin to activate adenylate cyclase; and (5) effects and characteristics of cytosolic factors, which stimulate adenylate cyclase in lung membranes.

Developmental changes in $\beta$-adrenergic receptors and basal adenylate cyclase activity in fresh homogenates. $\left[{ }^{3} \mathrm{H}\right] \mathrm{DHA}$ binding to rat lung homogenates increased 5-fold during development (Table 1). In contrast, basal adenylate cyclase activity in crude lung homogenates decreased significantly with increasing age: from $130-150 \mathrm{pmole} \cdot \mathrm{mg}^{-1} \cdot \mathrm{min}^{-1}$ in fetal and neonatal preparations to $25 \mathrm{pmole} \cdot \mathrm{mg}^{-1} \cdot \mathrm{min}^{-1}$ in the adult (Table 1). Activity in the presence of $10 \mathrm{mM} \mathrm{NaF}$ also decreased during this time period. Adenylate cyclase activity in crude lung homogenate was significantly enhanced by $\mathrm{NaF}, \mathrm{GTP},(-)$-isoproterenol or $\mathrm{PGE}_{1}$ in presence and absence of added GTP all ages, $P<0.01$, Table 2.

Ontogenic changes in washed membrane. Although $\beta$-adrenergic receptor density in washed lung membranes increased 5 -fold from day 20 of gestation to adulthood, basal- and NaF-dependent adenylate cyclase decreased slightly [53 \pm 4 to $37 \pm 9$ pmole. $\mathrm{mg}^{-1} \cdot \min ^{-1}$ (mean \pm S.D.)] during this period of development. The ontogenic decrease in adenylate cyclase, which was apparent in crude lung homogenate, contrasted with the small developmental decrease in the activity in washed particulate membranes. Activity in the washed membranes was also sensitive to GTP, $\mathrm{Gpp}(\mathrm{NH}) \mathrm{p}, \mathrm{NaF},(-)$-isoproterenol and $\mathrm{PGE}_{1}$ (Table 3). Maximal stimulation by $\mathrm{PGE}_{1}$ and (-)-isoproterenol required GTP in washed membrane; however, the marked activation of fetal adenylate cyclase by GTP in washed membranes (in the absence of hormone) obscured possible hormone-sensitive activity. Due to the marked differences in GTP-sensitive activity between fetal and adult lung membranes, more detailed comparisons between the effects of guanine nucleotides on receptor function and on adenylate cyclase were made.

Effect of guanine nucleotides on $\beta$-adrenergic receptor affinity. Guanine nucleotides are known to decrease agonist affinity for the receptor site in association with the ability of catecholamines to stimulate adenylate cyclase activity. The function of this component of the response system was therefore determined by the ability of $\mathrm{Gpp}(\mathrm{NH}) \mathrm{p}$ to decrease agonist affinity determined during competition experiments with (-)-isoproterenol and (-)$\left[{ }^{3} \mathrm{H}\right] \mathrm{DHA}$ binding to fetal and adult lung membranes. Gpp(NH)p significantly decreased agonist affinity for the receptor site. In fetal membrane preparations the $K_{D}$ for the inhibition of $\left[{ }^{3} \mathrm{H}\right]$ DHA binding by $(-)$-isoproterenol in the absence of guanine nucleotides was $4.2 \times 10^{-8} \mathrm{M}$, Hill coefficient, 0.58 . In the presence of $100 \mu \mathrm{M} \mathrm{Gpp}(\mathrm{NH}) \mathrm{p}$ the $\mathrm{K}_{\mathrm{D}}$ was $5.3 \times 10^{-7} \mathrm{M}$ and a homogeneous class of low affinity receptors identified with a Hill coefficient equal to 1.1 ; thus, the addition of guanine nucleotide decreased agonist affinity for $\beta$-adrenergic receptors as previously demonstrated in adult lung membrane as expected for a "coupled" receptor, $G / F$ interaction. 
Table 3. Adenylate cyclase in washed membrane $\left(P_{2}\right)$ from fetal and adult rat lung ${ }^{1}$

\begin{tabular}{|c|c|c|c|c|}
\hline & \multicolumn{2}{|c|}{ Fetal (20 day $)^{2}$} & \multicolumn{2}{|c|}{ Adult $(250 \mathrm{~g})^{3}$} \\
\hline & $\begin{array}{c}\text { cAMP } \\
\left(\mathrm{pmole} \cdot \mathrm{mg}^{-1} \cdot \mathrm{min}^{-1}\right)\end{array}$ & (fold activation) & $\begin{array}{c}\text { cAMP } \\
\left(\text { pmole } \cdot \mathrm{mg}^{-1} \cdot \min ^{-1}\right)\end{array}$ & (fold activation) \\
\hline Basal & $53 \pm 4$ & & $37 \pm 9$ & \\
\hline $\mathrm{MgCl}_{2}(50 \mathrm{mM})$ & $134 \pm 14$ & $2.5^{4}$ & $52 \pm 10$ & 1.4 \\
\hline $\operatorname{GTP}\left(10^{-5} \mathrm{M}\right)$ & $316 \pm 36$ & $6.0^{4}$ & $127 \pm 22$ & 3.4 \\
\hline $\mathrm{PGE}_{1}\left(2.5 \times 10^{-5} \mathrm{M}\right)+\mathrm{GTP}$ & $403 \pm 50$ & $7.6^{4}$ & $182 \pm 35$ & 4.9 \\
\hline (-)Isoproterenol $\left(10^{-5} \mathrm{M}\right)+\mathrm{GTP}$ & $338 \pm 39$ & $6.3^{4}$ & $168 \pm 27$ & 4.5 \\
\hline $\mathrm{MgCl}_{2}+\mathrm{GTP}$ & $250 \pm 32$ & $4.7^{4}$ & $87 \pm 19$ & 2.4 \\
\hline $\mathrm{NaF}(10 \mathrm{mM})$ & $382 \pm 69$ & 7.1 & $273 \pm 49$ & 7.6 \\
\hline
\end{tabular}

${ }^{1}$ Adenylate cyclase was determined in fetal and adult washed lung membranes $\left(\mathrm{P}_{2}\right)$ in triplicate assays after incubation for $10 \mathrm{~min}$ at $30^{\circ} \mathrm{C}$. GTP was present at $10^{-5} \mathrm{M}$ where indicated. Fold activation represents activity in the presence of agonist divided by basal activity. Agents enhanced basal activity significantly, $P<0.01$, except in the case of $\mathrm{MgCl}_{2}$ in adult preparations. In all cases activity in adult preparations was significantly lower than in fetal, $P<0.01$. $\beta$-Adrenergic receptor density in the washed membrane was $112 \pm 12$ fmoles $\left[{ }^{3} \mathrm{H}\right] \mathrm{DHA}$ bound $\mathrm{mg}^{-1} \mathrm{protein}(n=3$, mean \pm S.D. $)$ at 20 days gestation and $496 \pm 76(n=4)$ in the adult, $P<0.01$. The $\mathrm{K}_{\mathrm{D}}$, approximately $0.9 \mathrm{nM}$, did not change with age. Values are mean \pm S.D.

${ }^{2}$ Fetal $n=5$ (day 20).

${ }^{3}$ Adult $n=5$.

${ }^{4}$ Fold activation significantly higher in fetal than adult preparations, $P<0.01$.

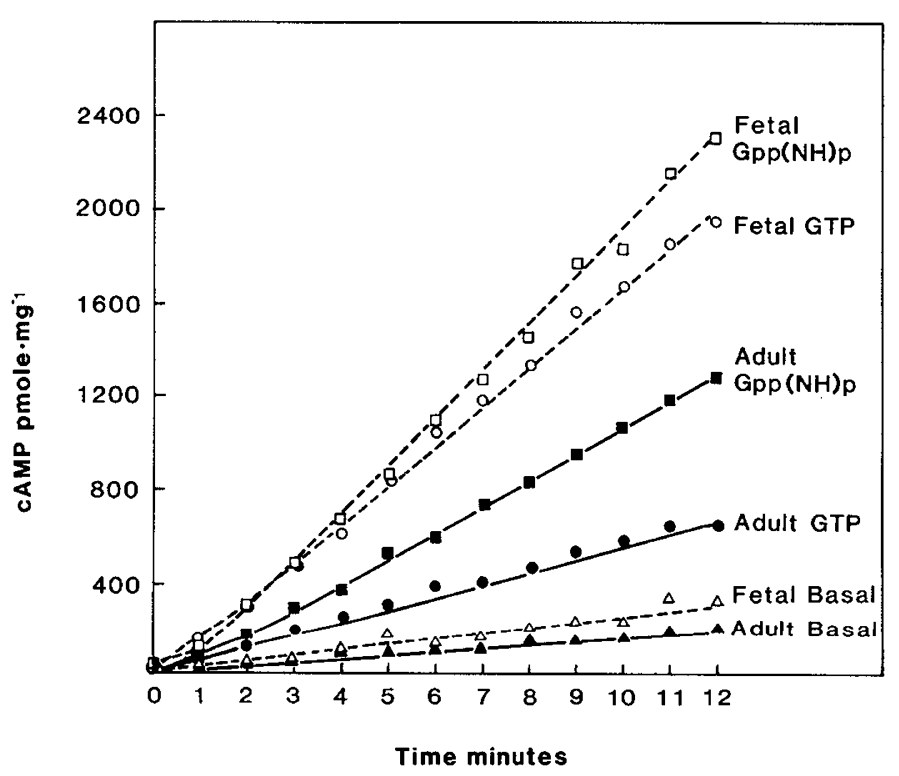

Fig. 1. Time course of adenylate cyclase activity in washed lung membrane from fetal (20 days gestation) and adult rat. Adenylate cyclase activity was determined as described in the "Materials and Methods" at each time point in the presence or absence of $10^{-5} \mathrm{M} \mathrm{Gpp}(\mathrm{NH}) \mathrm{p}$ or $10^{-5}$ $M$ GTP in fetal and adult preparations. The figure is representative of three such experiments with fetal and adult membranes.

Effects of GTP and Gpp(NH)p on catalytic adenylate cyclase activity. The time course of activation of adult and fetal lung membrane by GTP and Gpp(NH)p are represented by Figure 1 . GTP activated adenylate cyclase activity in fetal membrane to $83 \%$ of maximal (catalytic) activity, whereas GTP activated adult preparations to approximately $50 \%$ of maximum activity as determined with $10 \mathrm{mM} \mathrm{NaF}$ or $10^{-5} \mathrm{M} \mathrm{Gpp(NH)p.} \mathrm{The} \mathrm{EC50} \mathrm{of} \mathrm{the}$ activation of adenylate cyclase by GTP was approximately $7 \times$ $10^{-7} \mathrm{M}$ and was similar in both fetal and adult fractions (Fig. 2). Percent activation by GTP was significantly higher in fetal than in adult membranes, $P<0.01$ (Table 3 and Fig. 2).

The marked activation of fetal lung adenylate cyclase by GTP alone was not related to changes in endogenous catecholamines or prostaglandin $\mathrm{E}$ concentrations nor to changes in prostaglandin synthesis during incubations with membrane preparations. Alprenolol $\left(10^{-5} \mathrm{M}\right)$, a potent $\beta$-adrenergic antagonist, did not alter adenylate cyclase activity. Endogenous PGE concentration in the assay was determined by an assay which quantitates both $\mathrm{PGE}_{2}$

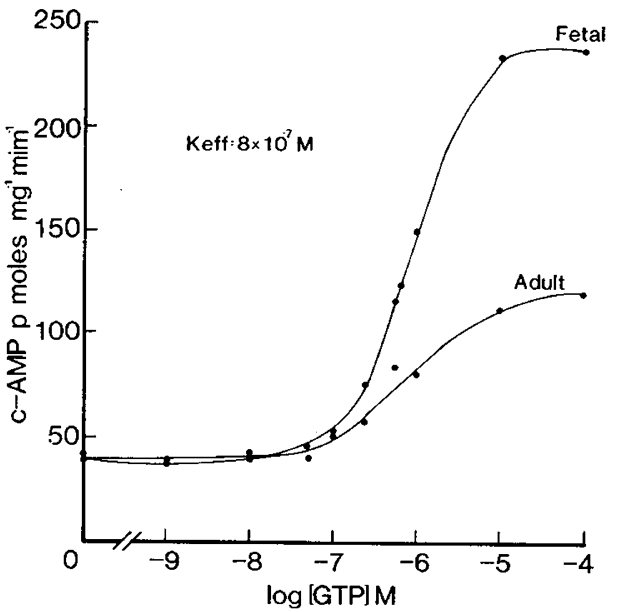

Fig. 2. GTP dependent activation of adenylate cyclase activity in washed lung membrane from fetal ( 20 days gestation) and adult rat. Adenylate cyclase activity was determined in triplicate in the presence of increasing concentrations of GTP as described in the "Materials and Methods." These curves are representative of three such experiments with fetal and adult membranes.

and $\mathrm{PGE}_{\mathrm{I}}$. The PGE concentration was approximately $2-4 \mathrm{nM}$ and was slightly higher in adult than in fetal membrane preparations when expressed per mg protein. Prostaglandin concentration did not change during the incubation procedure for the determination of adenylate cyclase. Likewise, $10 \mu \mathrm{g} / \mathrm{ml}$ indomethacin, added to inhibit possible endogenous prostaglandin synthesis, did not alter adenylate cyclase activity in either fetal or adult samples (data not shown).

Cytosol and cytosol inactivation studies. Fetal and adult cytosol markedly activated adenylate cyclase activity in both fetal and adult membranes (Fig. 3). In general, characteristics of adenylate cyclase activation by adult and fetal cytosolic preparations were similar. Activation of adenylate cyclase activity was always slightly, but consistently higher by fetal than by adult cytosol when expressed on the basis of cytosolic protein added to the assays. Activation by cytosol was always significantly higher when tested with membranes from fetal rather than adult lung. Ability of cytosol to activate either membrane was decreased approximately $20-30 \%$ by boiling. Activation by cytosol was significantly decreased when pretreated with trypsin (compared to incubation with trypsin in the presence of soybean trypsin inhibitor). The trypsin-sensitive component was consistently higher in adult than 


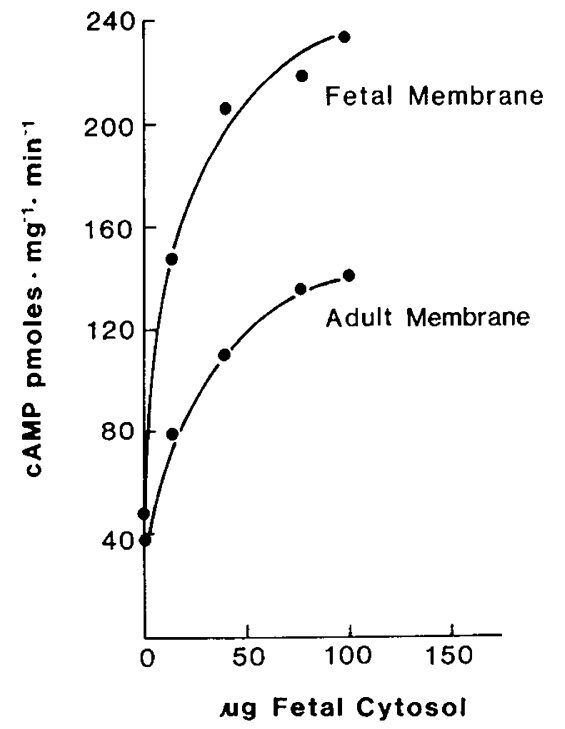

Fig. 3. Activation of adenylate cyclase activity in fetal (day 20 gestation) and adult lung membrane by the addition of lung cytosol. Lung cytosol (0-100 $\mu \mathrm{g}$ protein) was added to washed membranes from fetal and adult lung. Adenylate cyclase was determined in triplicate at each concentration as described in the "Materials and Methods." These curves are representative of three experiments in fetal and adult preparations.

fetal preparations. Trypsin decreased activation of adenylate cyclase by cytosol $49 \pm 3 \%(n=6)$ in adult cytosol compared to 31 $\pm 8 \%(n=6)$ in fetal cytosol, mean \pm S.D., $P<0.01$, after incubation for $30 \mathrm{~min}$ at $37^{\circ}$. Percent trypsin sensitivity was similar whether assessed with fetal or adult adenylate cyclase.

Cytosolic factors. Because of the likely presence of GTP in crude lung homogenates and marked differences in activation of fetal membrane by GTP, it was possible that ontogenic changes observed in basal activity in crude preparations were related to the presence of GTP or GTP-like factors present in cytosol which were removed during the preparation of the washed membrane fraction. Problems in extraction of GTP from the homogenization buffer made it impossible to assess GTP in subcellular fractions. GTP was therefore identified by high performance liquid chromatography in fresh rat lung extracted with perchloric acid. Tissue concentrations of GTP were similar in fetal and adult rat lung, $0.10 \pm 0.017 \mu$ mole per $g$ tissue and $0.06 \pm 0.03 \mu$ mole per $g$ tissue, mean \pm S.D., $n=3$ and four, respectively. The calculated concentration of GTP in the adenylate cyclase assay of crude homogenates was therefore approximately $10^{-7} \mathrm{M} \mathrm{GTP}$, a concentration similar to the EC50 for activation of adenylate cyclase by GTP.

Gel filtration. Fractions of adult and fetal cytosol were subjected to gel filtration on a Sephadex G-50 column and tested for their ability to activate adenylate cyclase activity in fetal or adult membranes (Fig. 4). Activity was present in two peaks of high and low molecular weight. Boiling samples before separation resulted in total loss of high molecular weight activity whereas activity in the small molecular weight fraction was unchanged. Activation of adenylate cyclase was similar whether fetal or adult membranes were used to test the cytosolic fractions.

ATP regeneration system. Maximal activation of adenylate cyclase by cytosolic fractions from both fetal and adult lung was dependent upon a phosphocreatine-creatine phosphokinase ATP regeneration system (Fig. 5). A lag period in activation of the enzyme by cytosol (several min) was consistently observed in time course experiments, suggesting that synthesis of activating factor(s) occurred during the early period of incubation. Effect of the regenerating system could not be duplicated by addition of myokinase and/or adenine deaminase $(10 \mathrm{U} / \mathrm{ml})$, both enzymes capable of catalyzing synthesis of guanine nucleotides.

Cholera toxin treatment. Adenylate cyclase activity was determined in membranes from fetal (day 20 of gestation) and adult rat lung after pretreatment with cholera toxin under conditions for $\mathrm{G} / \mathrm{F}$ factor ribosylation (Table 4). Basal activity was enhanced by cholera toxin in both fetal and adult samples. Cholera-toxin treatment of fetal membranes did not alter GTP-dependent activity. $\mathrm{Gpp}(\mathrm{NH}) \mathrm{p}$ or GTP, whether treated with cholera toxin or untreated, was nearly equal in activation of fetal lung adenylate cyclase activity. In contrast, cholera-toxin treatment significantly increased GTP-dependent adenylate cyclase activity in adult lung membranes, (Table 4). Finally, incubation of fetal enzyme at $37^{\circ} \mathrm{C}$

Fetal Membrane and Cytosol

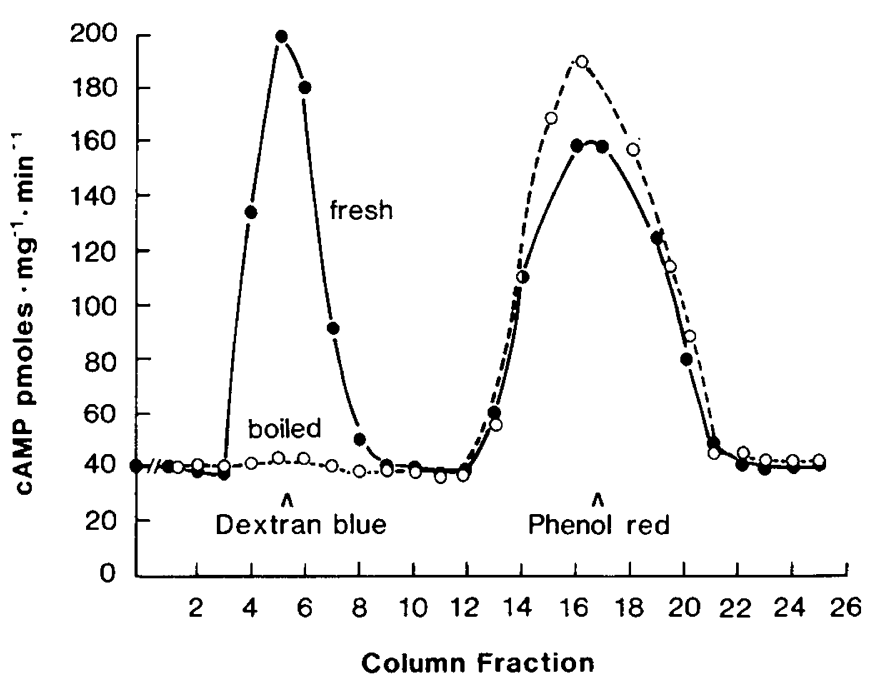

Fig. 4. Activation of fetal lung adenylate cyclase by column fractions of fetal lung cytosol separated by gel filtration. Approximately $5 \mathrm{mg}$ of cytosolic fetal lung protein was added to a $1 \times 25 \mathrm{~cm}$ column of Sephadex $\mathrm{G}-50$ at $2{ }^{\circ} \mathrm{C}$. The fractions $(0.5 \mathrm{cc})$ were collected and assessed for protein (not shown) and for the ability of $25 \mu \mathrm{l}$ of the eluate to activate fetal long adenylate cyclase. Samples were also heated to $100^{\circ} \mathrm{C}$ for $10 \mathrm{~min}$ and applied to the column for fetal and adult cytosol. The elution curve is similar for fetal and adult cytosol whether assessed in fetal or adult membrane, although activation was greater when tested with fetal membrane. High molecular weight activity was absent in the boiled sample (fractions 4-8).

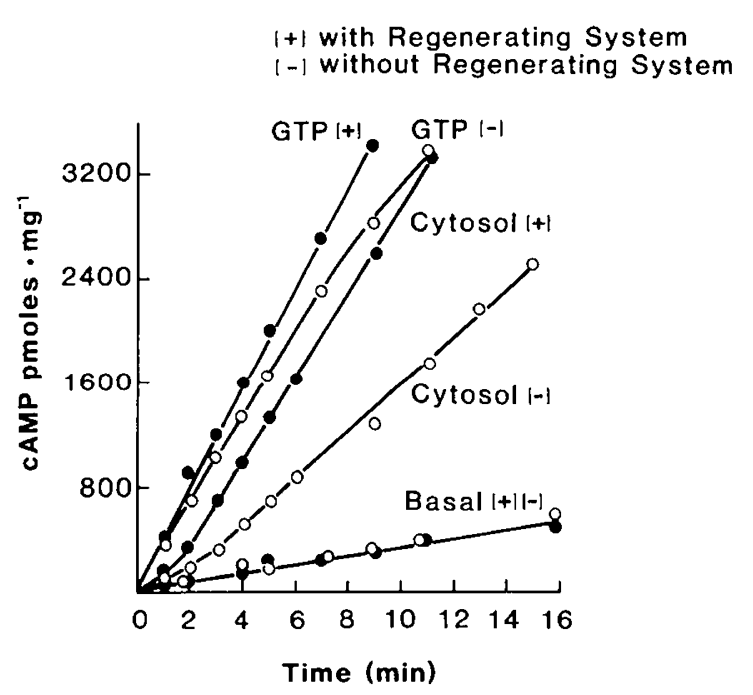

Fig. 5. Effect of the creatine phosphate and creatine phosphokinase regenerating system on adenylate cyclase activity in fetal lung membrane ( 20 days gestation). Adenylate cyclase was determined at each time point in the presence $(-0)$ or absence $\left(\mathrm{O}_{-} \mathrm{O}\right)$ of the regenerating system in the presence or absence of $10^{-5} \mathrm{M} \mathrm{GTP}$ or $100 \mu \mathrm{g}$ fetal lung. 
for $30 \mathrm{~min}$ in ribosylating buffer (without cholera toxin) selectively decreased the GTP-sensitive component of the fetal enzyme, resulting in a preparation which was activated to a greater extent by $\mathrm{NaF}$ than GTP, similar to the finding in untreated adult preparations (Table 4). Incubation of the membrane in STE (in the absence of the ribosylation buffer) lead to a progressive loss of enzyme activity suggesting that degradation of the enzyme occurs rapidly at $37^{\circ} \mathrm{C}$. Attempts to directly label G/F factor with cholera toxin in the presence of $\left[{ }^{32} \mathrm{P}\right] N A D$ were unsuccessful in both fetal and adult preparations. In contrast, ADP ribosylation of $G / F$ protein was routinely accomplished in human erythrocyte membranes (data not shown).

Magnesium. Adenylate cyclase activity required $\mathrm{Mg}^{2+}$ in both

Table 4. Adenylate cyclase activity $\left(\mathrm{pmoles} \cdot \mathrm{mg}^{-1} \cdot \mathrm{min}^{-1}\right)^{1}$

\begin{tabular}{|c|c|c|c|c|}
\hline & Basal & GTP & $\begin{array}{c}\text { GTP + } \\
\text { Cholera } \\
\text { toxin }\end{array}$ & $\begin{array}{c}\mathrm{NaF} \\
(10 \mathrm{mM})\end{array}$ \\
\hline \multicolumn{5}{|c|}{$\begin{array}{l}\text { Day } 20 \text { Fetal } \\
\quad(n=5)\end{array}$} \\
\hline Control & $53 \pm 4$ & $316 \pm 35$ & & $375 \pm 49$ \\
\hline Treated & $67 \pm 12$ & $119 \pm 20$ & $323 \pm 36$ & $292 \pm 41$ \\
\hline \multicolumn{5}{|c|}{ Adult $(n=5)$} \\
\hline Control & $37 \pm 9$ & $127 \pm 22$ & & $291 \pm 31$ \\
\hline Treated & $41 \pm 14$ & $83 \pm 16$ & $207 \pm 31^{2}$ & $231 \pm 30$ \\
\hline
\end{tabular}

1 "Control" represents activity in membranes prepared in STE. "Treated" represents activity after incubation for $30 \mathrm{~min}$ at $37^{\circ} \mathrm{C}$ in ribosylating buffer with cholera toxin (GTP + cholera toxin) or without (basal, GTP, NaF). Treated membranes were washed in iced STE buffer, resuspended, and adenylate cyclase activity assessed in triplicate in the presence of $10^{-5} \mathrm{M} \mathrm{GTP}$ or $10 \mathrm{mM} \mathrm{NaF}$. Incubation for $30 \mathrm{~min}$ at $37^{\circ} \mathrm{C}$ in STE alone resulted in marked loss of enzyme activity (not shown). Values are mean \pm S.D.

${ }^{2}$ GTP + cholera toxin $>$ GTP in control, $P<0.01$. fetal and adult preparations. $\mathrm{Mg}^{2+}$ dose responses of fetal and adult membranes are represented by Figure 6 . Activation was higher in fetal than adult preparations $(P<0.01)$ and the pattern of activation was markedly altered by addition of GTP (Table 3). In the absence of GTP, $\mathrm{Mg}^{2+}$ activated both fetal and adult enzymes at all concentrations. In contrast, a biphasic dose response was demonstrated in the presence of GTP in both fetal and adult preparations (Fig. 6 right hand panel). $\mathrm{Mg}^{2+}$ effects were similar whether $\mathrm{MgSO}_{4}$ or $\mathrm{MgCl}_{2}$ were utilized in the assay. Activation was not observed with the addition of $10-100 \mathrm{mM} \mathrm{NaCl}$.

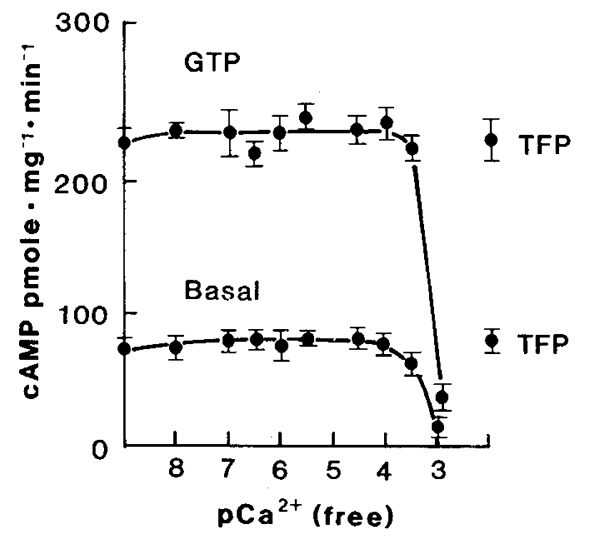

Fig. 7. Effect of $\mathrm{Ca}^{2+}$ on adenylate cyclase activity in lung membrane. Adenylate cyclase was determined in adult membranes in the presence of an EGTA buffer system ( $1 \mathrm{mM}$ EGTA) and increasing concentrations of $\mathrm{CaCl}_{2}$ to give estimated free $\mathrm{Ca}^{2+}$ indicated on the $\mathrm{x}$-axis. The assays were performed in triplicate in the presence of $10 \mu \mathrm{g} / \mathrm{ml}$ calmodulin. Calmodulin $(10 \mu \mathrm{g} / \mathrm{ml})$ or trifuoperazine $\left(10^{-5} \mathrm{M}\right.$ TFP) had no effect on basal or GTP-stimulated activity. Experiments performed with membranes which were extensively washed with STE (1 mM EGTA) resulted in identical results.
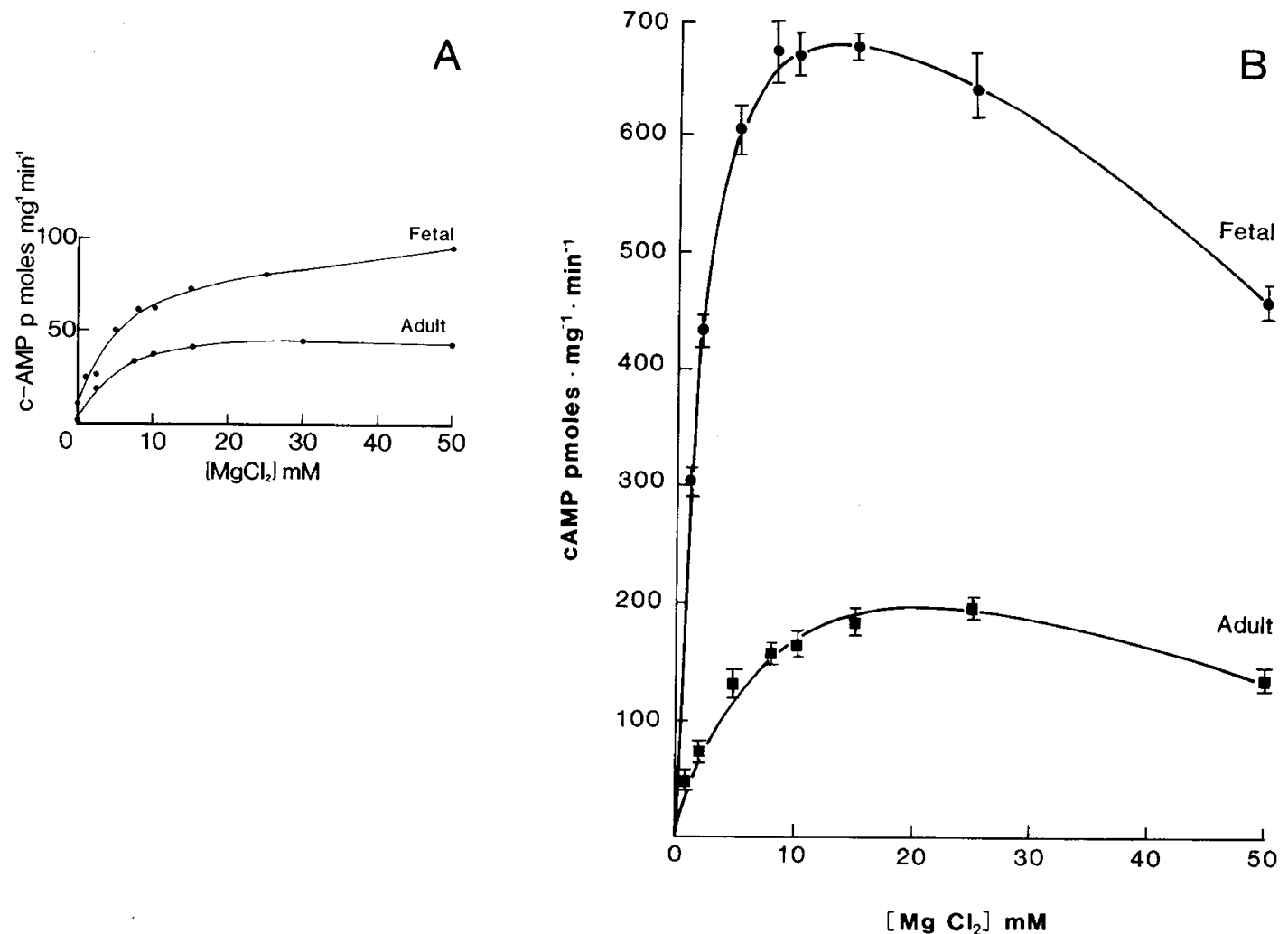

Fig. 6. $\mathrm{Mg}^{2+}$ dependency of adenylate cyclase activity in fetal and adult lung membranes. Adenylate cyclase activity was determined in the absence (left hand panel) and presence (right hand panel) of GTP $\left(10^{-5} \mathrm{M}\right)$ and increasing concentrations of $\mathrm{MgCl}_{2}(0.05-50 \mathrm{mM})$. Activity was determined in triplicate at each point and these figures are representative of 2-3 experiments in fetal ( 20 days gestation) and adult preparations. 
$E G T A$, calcium and calmodulin. In membranes prepared in the absence of chelators, adenylate cyclase activity was enhanced 2 3-fold by addition of EGTA (0.05-5 mM). The EC50 for activation was approximately $0.02 \mathrm{mM}$ EGTA. Endogenous $\mathrm{Ca}^{2+}$ in the buffer system with added membrane protein was approximately $10^{-6} \mathrm{M}$ (total $\mathrm{Ca}^{2+}$ ) as determined by flame spectroscopy; however, the stimulatory effect of EGTA on adenylate cyclase activity could not be explained by $\mathrm{Ca}^{2+}$ chelation. In the EGTA-Ca buffer system, increasing concentrations of free $\mathrm{Ca}^{2+}\left(10^{-8}\right.$ to $\left.10^{-4} \mathrm{M}\right)$, in the presence or absence of calmodulin, had no effect on adenylate cyclase activity from either fetal or adult preparations even after extensive washing of membrane in EGTA (STE) before assay. Concentrations of free $\mathrm{Ca}^{2+}$ in excess of EGTA $\left(10^{-3} \mathrm{M}\right)$ were inhibitory in both fetal and adult samples; however, neither a stimulatory nor inhibitory effect of $\mathrm{Ca}^{2+}$ or $\mathrm{Ca}^{2+}$-calmodulin was noted at more physiologic intracellular $\mathrm{Ca}^{2+}$ concentrations (Fig. 7). Trifluoperazine $\left(10^{-5} \mathrm{M}\right)$, known to inhibit calmodulin-dependent processes, had no effect on basal- or GTP-dependent activity. Calmodulin activity of lung homogenates did not change significantly with age ranging from $293 \pm 42 \mathrm{ng} / \mathrm{mg}$ protein in fetal lung homogenates at 18 days gestation to $203 \pm 28 \mathrm{ng} / \mathrm{mg}$ protein in adult samples, mean \pm S.E., $n=6$.

\section{DISCUSSION}

Our studies demonstrate ontogenic changes in the characteristics of adenylate cyclase and $\beta$-adrenergic receptors in the rat lung. Although the concentration of $\beta$-adrenergic receptors increased with age, basal adenylate cyclase activity in crude homogenates decreased during postnatal development. The marked decrease in basal activity was found to be associated with enhanced activation of fetal enzyme by GTP, and the presence of GTP, GTP producing or GTP-like cytosolic components present in crude lung homogenates. Adenylate cyclase activity in washed membrane fractions of fetal lung was markedly enhanced by GTP or Gpp(NH)p in the presence or absence of $(-)$-isoproterenol or $\mathrm{PGE}_{1}$. Maximal activation of adenylate cyclase by GTP, cytosol or $\mathrm{Mg}^{2+}$ was higher in fetal than adult membranes. At least two cytosolic components, which stimulated adenylate cyclase activity with the characteristics of GTP, were separated by gel filtration. One component is probably GTP, which was present in the crude homogenate assay at concentrations similar to the EC50 for activation of adenylate cyclase by GTP. The higher molecular weight component(s) were trypsin and heat sensitive. Developmental changes in the characteristics of catalytic adenylate cyclase activity and its interaction with guanine-nucleotide-dependent factors are also likely to be factors that account for these findings.

There is evidence that surfactant release and smooth muscle tone are regulated by catecholamines and prostaglandins and that the response of the lung to these stimuli changes with age. Although concentrations of pulmonary catecholamines and $\beta$-adrenergic receptors increase in the perinatal period, the relationship between catecholamine receptors and adenylate cyclase activity are unclear during development. Interpretation of ontogenic changes in hormonal sensitivity of adenylate cyclase activity has been confounded by a number of issues including the cellular heterogeneity of lung tissue, the high "basal" adenylate cyclase activity and poor coupling of the receptor to adenylate cyclase in lung homogenates and washed membranes. From the present study it is evident that basal activity is increased in crude lung homogenates (as compared to washed membranes) from fetal or suckling animals. This observation is associated with marked activation of fetal lung adenylate cyclase by endogenous GTP or GTP-like activity in cytosol, which is also present in crude homogenates. The EC50 for GTP activation was similar in fetal and adult samples; however, total activity and the \% activation of basal activity related to GTP or cytosol was much higher in fetal (6-fold activation) than in adult preparations (3-fold activation), possibly accounting for the high basal activity in crude homogenates from younger animals.

The marked effect of GTP on adenylate cyclase in fetal lung was not altered by the $\beta$-adrenergic antagonist, (-)-alprenolol; thus, heightened activation of fetal enzyme by GTP was not related to differences in endogenous catecholamines. Likewise, activation by endogenous prostaglandins did not account for the high activity in fetal preparations in the presence of GTP. PGE was present in the assay at relatively low concentrations $(2-4 \mathrm{nM})$ in comparison with the EC50 for $\mathrm{PGE}_{1}$, which is in the $\mu \mathrm{M}$ range (33). Furthermore, indomethacin, a prostaglandin synthesis inhibitor, did not alter adenylate cyclase activity. This supports the conclusion that possible prostaglandin synthesis during the incubation did not account for developmental differences in adenylate cyclase activity.

Although there was a small but significant decrease in NaFdependent adenylate cyclase activity in washed membranes with age, the difference in GTP response was clearly in excess of changes in "maximal catalytic activity" as defined with $\mathrm{NaF}$ or $\mathrm{Gpp}(\mathrm{NH}) \mathrm{p}$. The properties of activation of adenylate cyclase by GTP and $G p p(N H) p$ in washed membrane were similar to those reported in other systems: $(I)$ hormone stimulation by catecholamine or PGE 1 required GTP for maximal activation; (2) GTP was required for the inhibitory effect of $\mathrm{Mg}^{2+}$ at high $(50 \mathrm{mM})$ concentrations in washed membranes; (3) EC50 for GTP was similar to previous studies; and (4) a characteristic lag period was observed during the activation of the enzyme by $\mathrm{Gpp}(\mathrm{NH}) \mathrm{p}$ in the absence of hormone $(16,35)$.

Developmental changes in $\beta$-adrenergic receptors and their function have been demonstrated in numerous tissues whereas changes in $G / F$ factor interactions with either the receptor or catalytic subunit are less clearly defined $(5,11,17,32,37-39)$. GTP-induced changes in agonist affinity, adenylate cyclase activity, and $G / F$ interactions with the catalytic subunit are lost during maturation of the rat reticulocyte (17). We have demonstrated previously a decreased ability of GTP or Gpp(NH)p to decrease agonist affinity of $\beta$-adrenergic receptors in fetal rabbit lung supporting the concept that a maturational change in $G / F$ factor(s) is associated with maturation of the $\beta$-adrenergic receptor system in this species (38). In contrast, $\mathrm{Gpp}(\mathrm{NH}) \mathrm{p}$ significantly decreased agonist affinity in fetal rat lung membrane resulting in an apparent homogenous population of low affinity $\beta$-adrenergic sites (Hill coefficient approximately 1.0); therefore, regulation of agonist affinity by guanine nucleotides appears to be intact in fetal rat lung. It is possible that ontogenic differences in GTP and $\mathrm{Mg}^{2+}$ sensitivity reflect changes in $\mathrm{G} / \mathrm{F}$ factor(s) or their interactions with the catalytic subunit in developing lung. Pike and Lefkowitz (31) have recently ascribed differences in basal- and GTP-sensitive adenylate cyclase activity between turkey erythrocyte and frog erythrocyte to differences in the rate of GDP dissociation from the $\mathrm{G} / \mathrm{F}$ binding site, which is associated with hormone sensitive GTPase. Frog erythrocyte, unlike the turkey erythrocyte, has a basal- and GTP-dependent activity in the absence of hormone that is related to an increased rate of dissociation of GDP from its binding site. A similar mechanism may account for the high GTP-sensitive component in fetal rat lung however, such detailed studies are not possible in the crude lung preparations used in our study.

Because cholera toxin treatment of adult rat lung membrane results in a preparation that is similar to that from fetal lung in its response to GTP, it is intriguing to question whether GTP is so effective in young animals because the $G / F$ protein(s) are endogenously ribosylated. There is no evidence to support this hypothesis but in the present study, attempts to demonstrate $G / F$ factors by the phosphorylation of the $G / F$ proteins with cholera toxin and $\left.{ }^{32} \mathrm{P}\right]$ NAD were unsuccessful in both fetal and adult preparations. Presence of endogenous ADP-dependent ribosylation activity has been demonstrated previously in mammalian tissues (22). Changes in proportion of specific cell types with characteristic high activation by GTP might also explain the observed changes although drastic changes in cell type are not known to occur in the postnatal period.

At least two cytosolic components activated adenylate cyclase in rat lung membrane. Cytosolic factors, which enhance adenylate 
cyclase activity, have been demonstrated in several studies and several hypotheses have been suggested for their mechanism of action. In general, cytosolic factors activate adenylate cyclase with the properties expected by addition of GTP $(7,20,27,29)$. GTP or other nucleotides, GTP-generating or binding proteins, have been factors previously suggested $(7,20,27)$. Effects of cytosol on lung adenylate cyclase do not seem to be mediated by $\mathrm{Ca}^{2+}$ or calmodulin. $\mathrm{Ca}^{2+}$-calmodulin has been clearly demonstrated as a cytosolic factor that activates brain adenylate cyclase (30). Although Ofulue and Nijjar (26) recently reported $\mathrm{Ca}^{2+}$-calmodulin stimulation of rat lung adenylate cyclase, we are unable to confirm this finding. The properties of basal activity and cytosolic factors in rat lung presently described are also clearly distinct from those reported by Nijjar et al. (23), who found that GTP did not stimulate rat lung membranes at any age. In those studies, adenylate cyclase activity in crude lung preparations increased with age and adenylate cyclase activity was in general much lower than in the present work. The reasons for these differences are not clear nor are they entirely related to the membrane preparation procedures. Membranes prepared in identical fashion to those previously reported (23) were as highly activated by GTP as those prepared by our present procedures. It is possible that use of fresh samples, presence of EGTA during storage and assay, and the use of a creatine-phosphate-ATP regeneration system may account for some of these differences (12). Although we also describe cytosolic factors that enhance adenylate cyclase activity in the rat lung, the properties of adenylate cyclase activation by cytosol are similar to those of activation by GTP.

Identification of the cytosolic factors has not been established. It is probable, however, that GTP is one of the factors. It is also likely that the higher molecular weight activity is protein in nature, being trypsin- and heat-sensitive. Enzymes such as myokinase and adenosine deaminase, which might support GTP synthesis from other nucleotides in the assay, did not increase adenylate cyclase activity. The lag in the time course of activation and the dependency of cytosolic activation on the phosphocreatine regenerating system suggest that changes in nucleotide concentrations may be involved in the effects of cytosol on adenylate cyclase activation.

Ontogenic changes in adenylate cyclase activity in crude lung homogenates may be related to both the presence of endogenous GTP, to substrates which are activated by the nucleotide regenerating system, and by trypsin sensitive factor(s) that support GTP-like activity. The marked ontogenic decrease in basal activity in crude homogenates is likely to result from the enhanced stimulation of adenylate cyclase activity in young rats by GTP and GTP-like factor(s). The heightened activation by GTP may be related to developmental changes in the $\mathrm{G} / \mathrm{F}$ coupling factor(s) and its interaction with the catalytic subunit of adenylate cyclase. Finally the ontogenic changes in adenylate cyclase activity appear to be distinct from those of $\beta$-adrenergic receptors in the rat lung.

Pulmonary smooth muscle tone, surfactant release and pulmonary fluid secretion are regulated by catecholamines. Ontogenic changes in lung responses to catecholamines are likely to be mediated, in part, by ontogenic differences in the complex interactions among the components constituting the $\beta$-adrenergic response system: $\beta$-adrenergic receptors, guanine nucleotide dependent $(G / F)$ factors, cytosolic factors and the catalytic activity of adenylate cyclase.

\section{REFERENCES AND NOTES}

1. Barrett, C. T., Sevanian, A., and Kaplan, S. A.: Adenylate cyclase activity in immature rabbit lung. Pediatr. Res., 8: 244 (1974).

2. Brown, L. A. and Longmore, W. J.: Adrenergic and cholinergic regulation of lung surfactant secretion in the isolated perfused lung and in the alveolar Type II cell in culture. J. Biol. Chem., 256: 66 (1981).

3. Cassel, D., Eckstein, F., Lowe, M., and Selinger, Z.: Determination of the turnoff reaction for the hormone-activated adenylate cyclase. J. Biol. Chem., 254: 9835 (1979).

4. Cassel, D. and Selinger, Z.: Mechanism of adenylate cyclase activation by cholera toxin: Inhibition of GTP hydrolysis at the regulatory site. Proc. Natl. Acad. Sci., 74: 3307 (1977).
5. Cheng, J.B., Goldfien, A., Ballard, P. L., and Roberts, J. M.: Glucocorticoids increase pulmonary $\beta$-adrenergic receptors in fetal rabbit. Endocrinology, 107: 1646 (1980).

6. Clark, R. B.: Endogenous GTP and the regulation of epinephrine stimulation of adenylate cyclase. J. Cyclic Nucleotide Res., 4: 71 (1978).

7. Crawford, A., MacNeil, S., Amirrasooli, H., and Tomlinson, S.: Properties of a factor in cytosol that enhances hormone-stimulated adenylate cyclase activity. Biochem. J., I88: 401 (1980).

8. Dedman, J. R. and Means, A. R.: Characterization of a spectrophotometric assay for cAMP phosphodiesterase. J. Cyclic Nucleotide Res., 3: 139 (1977).

9. Dobbs, L. G. and Mason, R. J.: Pulmonary alveolar Type II cells isolated from rats: release of phosphotidylcholine in response to $\beta$-adrenergic stimulation. J. Clin. Invest., 63: 378 (1979).

10. Enomoto, K. and Gill, D. M.: Cholera toxin activation of adenylate cyclase. J. Biol. Chem., 255: 1252 (1980).

11. Giannopoulos, G.: Identification and ontogeny of $\beta$-adrenergic receptors in fetal rabbit lung. Biochem. Biophys. Res. Commun., 95: 388 (1980).

12. Johnson, R. A.: Stimulatory and inhibitory effects of ATP-regenerating systems on liver adenylate cyclase. J. Biol. Chem., 155: 8252 (1980).

13. Katz, M. S., Partilla, J. S., Pineyro, M. A., and Gregerman, R. I.: Determinants of the stimulation of fat cell adenylate cyclase by high concentrations of sodium and magnesium salts. Implications for the role of magnesium in regulation of enzyme activity. Biochem. Biophys. Acta, 613: 229 (1980).

14. Klein, K. L., Scott, W. J., and Clark, K. E.: Measurement of prostaglandins in embryonic tissue using radiommunoassay. Prostaglandins, 22(4): 623 (1981).

15. Kuo, J.F.: Reciprocal changes in levels of guanosine $3^{\prime}, 5^{\prime}$-monophosphate-dependent protein kinase in developing guinea pig lungs. J. Cyclic. Nucleotide Res., 1: 151 (1975).

16. Lefkowitz, R. J. and Williams, L. T.: Molecular mechanisms of activation and desensitization of adenylate cyclase coupled to $\beta$-adrenergic receptors. Adv. Cyclic Nucleotide Res., 9: 1 (1978)

17. Limbird, L. E., Gill, D. M., Stadel, J. M., Hickey, A. R., and Lefkowitz, R. J.: Loss of $\beta$-adrenergic receptor-guanine nucleotide regulatory protein interactions accompanies decline in catecholamine responsiveness of adenylate cyclase in maturing rat erythrocytes. J. Biol. Chem., 255: 1854 (1980).

18. Londos, C. and Preston, M. S.: Activation of the hepatic adenylate cyclase system by divalent cations. J. Biol. Chem., 252: 5957 (1977).

19. Lowry, O. H., Rosebrough, N. J., Farr, A. L., and Randall, R. J.: Protein measurements with the folin phenol reagent. J. Biol. Chem., 193: 265 (1951).

20. MacNeil, S., Crawford, A., Amirrasooli, H., Johnson, S., Pollock, A., Ollis, C., and Tomlinson, S.: Stimulation of hormone-responsive adenylate cyclase activity by a factor present in the cell cytosol. Biochem. J., 188: 393 (1980).

21. Mettler, N. R., Gray, M. E., Schuffman, S., and LaQuire, V. S.: $\beta$-Adrenergic induced synthesis and secretion of phosphatidylcholine by isolated pulmonary alveolar Type II cells. Lab. Invest., 45: 475 (1981).

22. Moss, J. and Vaughn, M.: Isolation of an avian erythrocyte protein possessing ADP-ribosyltransferase activity and capable of activating adenylate cyclase. Proc. Natl. Acad. Sci. USA, 75: 3621 (1978).

23. Nijjar, M. S.: Regulation of rat lung adenylate cyclase by cytoplasmic factor(s) during development. Biochim. Biophys. Acta, 584: 43 (1979).

24. Nijjar, M. S.: Role of cyclic AMP and related enzymes in rat lung growth and development. Biochim. Biophys. Acta, 586: 464 (1979).

25. Nijjar, M. S. and Ho, J. C.: Isolation of plasma membranes from rat lungs. Effects of age on the subcellular distribution of adenylate cyclase activity. Biochim. Biophys. Acta, 600: 238 (1980).

26. Ofulue, A. F. and Nijjar, M. S.: Calmodulin activation of rat lung adenylate cyclase is independent of the cytoplasmic factors modulating the enzyme. Biochem. J., 200: 475 (1981).

27. Ollis, C. A., Tomlinson, S., MacNeil, S., Crawford, A., and Munro, D. S.: A factor in cytosol enhances stimulation of membrane adenylate cyclase from human thyroid by thyrotrophin and thyroid stimulating immunoglobulins. FEBS Lett., 107: 269 (1979).

28. Palmer, G.: Characteristics of the hormonal induced $3^{\prime}, 5^{\prime}$-cyclic adenosine monophosphate response in the rat and guinea pig lung in vitro. Biochem. Biophys. Acta, 252: 561 (1971).

29. Pecker, F. and Hanoune, J.: Activation of epinephrine-sensitive adenylate cyclase in rat liver by cytosolic protein nucleotide complex. J. Biol. Chem., 252: 2784 (1977).

30. Piascik, M. T., Wisler, P. L., Johnson, C. L., and Potter, J. D.: $\mathrm{Ca}^{2+}$-dependent regulation of guinea pig brain adenylate cyclase. J. Biol. Chem., 255: 4176 (1980).

31. Pike, L. J. and Lefkowitz, R. J.: Correlation of $\beta$-adrenergic receptor stimulated $\left[{ }^{3} \mathrm{H}\right] \mathrm{GDP}$ release and adenylate cyclase activity. J. Biol. Chem., 256: 2207 (1981).

32. Pittman, R. N., Minneman, K. P., and Molinoff, P. B.: Ontogeny of $\beta_{1^{-}}$and $\beta_{2^{-}}$ adrenergic receptors in rat cerebellum and cerebral cortex. Brain Res., 188 : 357 (1980).

33. Powell, W. S. and Solomon, S.: Effects of prostaglandins on the adenylate cyclase activity of lungs from fetal rabbits. Endocrinology, 107: 1469 (1980).

34. Ritter, E. and Bruce, L.: Quantitative determination of deoxyribonucleotide triphosphates using high performance liquid chromotography. Biochem. Med., 21: $16(1980)$

35. Ross, E. M. and Gilman, A. G.: Biochemical properties of hormone sensitive adenylate cyclase. Ann. Rev. Biochem., 49: 533 (1980).

36. Salomon, Y., Londos, C., and Rodbell, M.: A highly sensitive adenylate cyclase assay. Anal. Biochem., 58: 541 (1974).

37. Whitsett, J. A., Manton, J. A., Darovec-Beckerman, C., and Adams, K.: $\beta$ - 
Adrenergic receptors and catecholamine sensitive adenylate cyclase in the developing rat lung. Life Sci., 28(4): 339 (1981).

38. Whitsett, J. A., Manton, M. A., Darovec-Beckerman, C., Adams, K. G., and Moore, J. J.: $\beta$-Adrenergic receptors in the developing rabbit lung. Am. J. Physiol., 240: E351 (1981).

39. Whitsett, J. A. and Darovec-Beckerman, C.: Developmental aspects of $\beta$-adrenergic receptors and catecholamine-sensitive adenylate cyclase in rat myocardium. Pediatr. Res., 15: 1361 (1981).

40. Williams, L. T., Mullikin, D., and Lefkowitz, R. J.: Magnesium dependence of agonist binding to adenylate cyclase-coupled hormone receptors. J. Biol. Chem., 253: 2984 (1978).

Copyright $\odot 1983$ International Pediatric Research Foundation, Inc. $0031-3998 / 83 / 1707-0553 \$ 02.00 / 0$
41. The authors thank Edmond Ritter, Ph.D., Children's Hospital, Cincinnati, and Kenneth Clark, Ph.D., University of Cincinnati, for their help in analysis of guanine nucleotides and prostaglandins, respectively.

42. Requests for reprints should be addressed to: Dr. Jeffrey A. Whitsett, Department of Pediatrics, Newborn Division, University of Cincinnati College of Medicine, 6210 Medical Science Building, 231 Bethesda Ave., Cincinnati, OH 45267.

43. Supported by the Children's Hospital Research Foundation, RCDA HL 01024. HL 28623, HD 11725 and NICHD Grant 11740 [J.A.W.] and Training Grant DHHSMCT 001174 [W.R.R.], and CLINFO RR 00068-18-52.

44. Received for publication July 1, 1982.

45. Accepted for publication December 6, 1982. 